\title{
THE EMERGENCE OF A HOLISTIC MARKETING CONCEPT IN THE MARKET ORIENTATION CONSTRUCT - VALIDATION OF A NEW MEASUREMENT TOOL
}

\author{
[Vznik holistického konceptu marketingu v rámci marketingové orientace - \\ ověření nového nástroje měření]
}

\author{
Bence Kovács ${ }^{1}$, Zoltán Szakály², Enikő Kontor ${ }^{3}$ \\ ${ }^{1}$ University of Debrecen, Faculty of Economics and Business, Böszörményi Str. 138. Debrecen, 4032 Hungary \\ Email: kovacs.bence@econ.unideb.hu \\ ${ }^{2}$ University of Debrecen, Faculty of Economics and Business, Böszörményi Str. 138. Debrecen, 4032 Hungary \\ Email: szakaly.zoltan@econ.unideb.hu
}

${ }^{3}$ University of Debrecen, Faculty of Economics and Business, Böszörményi Str. 138. Debrecen, 4032 Hungary Email: kontor.eniko@econ.unideb.hu

\begin{abstract}
The current study examines the most modern approach of the marketing concept, the socalled holistic marketing concept in small and medium-sized Hungarian enterprises in the food industry. The study attempts to match the holistic marketing concept to the construction of market orientation. The most widely accepted approaches of market orientation (behavioural and cultural) derive from the marketing concept, and they identify how the organisation tries to adopt the marketing concept during its operation. The research is based on a questionnaire survey of 150 companies. To examine the validity of the scale, the following calculations were performed: Cronbach's alpha, the composite reliability index, McDonald's omega, the Fornell-Larcker criterion and the CFA analysis. After the validation process, the authors found four dimensions. They are as follows: Internal Marketing, Integrated Marketing, Relationship Marketing and Societal Marketing. According to the authors, the holistic marketing concept can be a new approach of market orientation which can model, in a more suitable way, the modern and changed market conditions to measure and examine the adopted level of market orientation.
\end{abstract}

Keywords: holistic marketing concept, market orientation, small and medium-sized enterprises, validation.

JEL classification: C52, L25, M14, M31

Received: 10.2.2021; Reviewed: 1.3.2021; 5.3.2021; Accepted: 19.5.2021

\section{Introduction}

The coordination mechanism that generally prevails in market economies is provided by the market institution. It is crucial that it is effectively connected with the entity directly related to it, the company. The question arises: what kind of policy should guide the operation of a company in a dynamically changing environment? As early as at the beginning of the1990s, Kohli and Jaworski (1990) expressed the view that theoretical principles can only be put into practice to a limited extent. Among the answers to the formulated dilemma, the authors focused on the implementation of the marketing concept and the strengthening of its practical side. In this sense, market orientation is a practical implementation of the marketing concept, in which there is a consensus among researchers, and the measurement tools developed to measure market orientation follow this principle (Kohli and Jaworski 1990, Narver and Slater 1990).

The philosophy of the marketing concept assumes that the key to achieving organizational goals is that the company is more effective than competitors in creating, delivering, and communicating customer value to the selected target market. The marketing concept is based 
on two main pillars: customer orientation and long-term profitability, which are further enhanced by target market focus and integrated/coordinated marketing. However, Kotler and Keller (2012) propose that a significant number of companies now operate in a way that is increasingly compatible with the holistic marketing concept, i.e. companies focus not only on long-term profit-making but also on customer satisfaction, supplemented with performance, internal, integrated and relationship marketing. Customer orientation and competitor orientation permeate these four areas, while they reflect the role of intelligence sharing and dissemination as well as advanced response mechanisms. Companies applying a holistic marketing concept rely on the development and design of programs, processes, and activities that pay attention to the interdependence of specific tasks.

The aim of the present article is to adapt the holistic marketing concept to make market orientation more effective and realistically measurable in the changed circumstances of today's modern market economy. So our goal is to develop a measurement tool that is suitable for measuring marketing orientation based on a new, holistic approach to the marketing concept.

\section{Approaches to market orientation}

The first proposal of the market orientation concept is attributed to Shapiro (1988), who approached market orientation from the viewpoint of the method and process of organizational decision-making. At the same time - as, inter alia, Kovács et al. (2017) point out in their analysis - two articles (from two different pairs of authors) were published in 1990, which were perhaps equivalent in effect to the highest possible impact on the foundation of the conceptual basis of market orientation and the development of a methodology that also allows the determination of the adapted degree of market orientation. Kohli and Jaworski's (1990) approach to market information may be the closest to the strategic approach, and the essence is that companies collect and disseminate the necessary information to boost the efficiency of inter-functional coordination. Accordingly, three critical, culturally-based elements of market orientation are identified: 1. Allocation of market information at organization-level, based on consumer needs (intelligence generation). 2. Dissemination of the obtained information between the organizational units (intelligence dissemination). 3. The responsiveness of a firm to information.

The other, so-called behaviour-based approach is attributed to the names of another pair of authors, Narver and Slater (1990). Their research focused on lasting competitive advantage and a strong corporate culture. As they defined, market orientation is an organizational culture that most effectively and efficiently induces, relative to other organizational cultures, behaviour that creates outstanding customer value and thus contributes to higher business performance. Within this, three behavioural variables were identified, in the presence of which we can speak of market orientation. These are customer and competitor orientation and coordination between organizational units. Furthermore, the authors set two conditions for market orientation to be met: the company must operate with long-term goals in mind, aiming for long-term profit focus and profitability (Narver and Slater 1990).

After the publication of the two defining articles, the issue of market orientation came to the forefront of research. Desphandé et al.'s (1993) conception emphasizes the focus of organizational culture and consumer needs on companies. In addition to the customer approach, there is another so-called strategic approach that can be linked to Ruekert's name, which places consumer information in a strategic context (Ruekert 1992). 
In conclusion, although there are several approaches to market orientation, two perspectives are generally identified. The behavioural one (Narver and Slater 1990) focuses more on action and activity, how the organization obtains information and how it treats the acquired information. On the other hand, the cultural approach (Kohli and Jaworski 1990) places emphasis on certain components of organizational culture, norms, values, and attitudes (Becker and Homburg 1999). Another research summary identified five approaches by which research can be classified into at least one of the decision-making, strategic, market intelligence, cultural-based behaviour, and consumer-oriented perspectives of market orientation (Lafferty and Hult 2001).

\section{Measurement of market orientation}

Once the theoretical basis of market orientation has been defined, it has become important to make it measurable in some way. The following section of the paper will introduce the three most common measurement methods: the MARKOR, MKTOR, and DFW scales. All three measures use the so-called Likert scale. Depending on the theoretical basis, the authors determined the scales' dimensions (such as competitor orientation, customer orientation and inter-functional coordination), then variables that have become measurable activities were added to each dimension. These became the indicators of the measurement model, whereas dimensions were latent variables in the model. Against this background, market orientation is a latent variable determined by latent variables (dimensions). Thus, the models can be regarded as a multi-level, hierarchical relationship. A characteristic of the models is that they do not define levels below which a company can be considered market oriented or non-market oriented.

The MARKOR scale is based on the behavioural approach of Kohli and Jaworski. The scale originally consisted of 20, later 32 factors and defines market orientation along three dimensions: intelligence generation, intelligence dissemination and responsiveness, which have been explained in detail above (Kohli et al. 1993).

The MKTOR scale is based on the culturally-based perspective of Narver and Slater. However, as cultural factors are difficult to measure objectively, the three dimensions of the scale (competitor orientation, customer orientation, and interfunctional coordination) determine the degree of market orientation initially with 15 and later with 17 behavioural components/indicators (Narver and Slater 1990, Brettel et al. 2007).

Desphandé et al. (1993) constructed a nine-statement scale (DFW) that measures the level of market orientation by measuring customer orientation, corporate culture, and organizational innovation. Later, Desphandé and Farley (2004) reviewed their previous results and synthesized the three scales to create a hybrid tool (MORTN) that focused primarily on customer orientation and was composed of 10 statements.

Efforts to develop market-oriented thinking have also emerged in the development of measurement tools. The article by González-Benito and González-Benito (2005) reveals that approximately $40 \%$ of market orientation research uses the MARKOR and 35\% the MKTOR scale, and only $5 \%$ consider both theories. They concluded that although the bases of the scales are different, they are not mutually exclusive in measuring the level of market orientation, as the two scales measure the same phenomenon from different aspects with adequate efficiency and similar results. Oczkowski and Farrell (1997) analyzed both the MARKOR and MKTOR scales with reliability and validity studies. Their results suggest, that although the dimensions of both scales can be considered reliable based on Cronbach's alpha, the CFA analysis does not confirm this, and significant adaptations of the scales are needed. 
In the nearly 30 years since the model was constructed, the literature on market orientation expanded and evolved, and the market has also undergone a number of changes. Several studies have examined the validity and effectiveness of the scales, and a significant proportion of the research activities studied by the authors agrees that the adaptation of tools is necessary (Bareith et al. 2013). Farrell (2002) compared the development efforts of the MARKOR and MKTOR scales and came to the conclusion that in many cases, we may encounter unfounded, haphazard modifications and improvements. In our opinion, however, we also find a good number of methodologically well-founded studies. Studying the modification procedures, we found that the research efforts are divided: some of them attempt to improve existing scales using purely quantitative procedures (Dawes 2000, Harrison and Walker 2001, Hajjat 2002) or based on the Cronbach's alpha index, which measures the reliability of scales or, with more advanced, multiple statistical techniques, using confirmatory factor analysis or structural equation modelling (Jangl 2016, Frösén et al. 2016). Others logically focus on the literature or qualitative studies (in-depth interview, expert interview, focus group) (Oczkowski and Farrell 1997, Avlonitis and Gounaris 1999, Dawes 2000).

\section{Material and method}

The current research is based on questionnaire-based telephone interviews, during which 150 small and medium-sized enterprises in the Hungarian food industry were interviewed. The survey was conducted in 2019, by the Szocio-Gráf Market Resesarch Ltd., based in Pécs. The sampling frame was provided by the database of the Opten company. Respondents were selected from the database using a random number generator from Microsoft Excel. The focus of the research was on SMEs operating as co-enterprises in the food industry, according to size based on headcount. The sample is representative in this respect $(\chi 2(2)=5,51 ; p=0,06)$.

Table 1: The composition of the sample according to size $(n=150)$

\begin{tabular}{|l|l|l|}
\hline Size & Enterprises (n) & Distribution (\%) \\
\hline Micro & 89 & 59.3 \\
\hline Small & 46 & 30.7 \\
\hline Medium & 15 & 10.0 \\
\hline
\end{tabular}

Source: authors' own editing

In 2019, there were 4,566 economic organizations registered in the CSO (Central Statistical Office) register, which met the following conditions: SME size category, TEÁOR (Statistical Classification of Economic Activities) code in the CE category (manufacturing food, beverages and tobacco products), operating in the form of a partnership, and having more than zero employees. With $95 \%$ confidence level and $10 \%$ margin of error, the required sample number is 95, based on Gill et al. (2010). The sample size, therefore, meets the requirements for generalizability.

The set of statements used to measure holistic marketing was developed based on the book by Kotler and Keller (2012). The analysis was performed with R Statistics, version 3.4.2 in the R Studio editor, using the following packages: psych and lavaan. Exceptions to this are the AVE and CR indicators, which have traditionally been calculated manually in the absence of a reliable software pack.

\section{Results}

\subsection{Modelling the holistic marketing concept}

The model measuring the holistic marketing concept was developed based on Kotler and Keller (2012). According to that, the latent variables of the model are as follows: relationship marketing, integrated marketing, internal marketing, performance marketing. During the 
development of the measurement model, special attention was paid to have at least five measurement variables per dimension. Since performance marketing includes the attempt to improve marketing effectiveness and efficiency and also, a society-oriented marketing philosophy, six measurement variables were identified, in case the one-dimensionality of performance marketing is not met, i.e. the effectiveness/efficiency of marketing and the company's society-oriented marketing approach formed a separate latent variable. All variables of the measurement model are presented below, which will later be limited for the sake of the validity and reliability of the model, i.e. all measurement variables (statements) that would degrade reliability or cause invalidity will be removed.

Table 2: Relationship marketing

\begin{tabular}{|l|c|c|c|c|c|c|}
\hline \multicolumn{1}{|c|}{ Statements } & Mean & Median & Mode & $\begin{array}{c}\text { Standard } \\
\text { deviation }\end{array}$ & $\begin{array}{c}\text { Coefficient } \\
\text { of variation }\end{array}$ & Skewness \\
\hline $\begin{array}{l}\text { A key goal is to build deep, lasting } \\
\text { relationships with individuals and } \\
\text { organizations that have an impact on the } \\
\text { success of the company. }(n=149)\end{array}$ & 4.63 & 5 & 5 & 0.76 & $16 \%$ & -2.40 \\
\hline $\begin{array}{l}\text { Long-term partnerships are based on } \\
\text { mutual satisfaction. }(n=150)\end{array}$ & 4.91 & 5 & 5 & 0.38 & $8 \%$ & -5.23 \\
\hline $\begin{array}{l}\text { Particular importance is attached to the } \\
\text { relationship with customers. }(n=150)\end{array}$ & 4.86 & 5 & 5 & 0.37 & $8 \%$ & -2.50 \\
\hline $\begin{array}{l}\text { Particular importance is attached to the } \\
\text { relationship with partners (suppliers, } \\
\text { allies, distributors, agencies, investors). } \\
\text { (n=149) }\end{array}$ & 4.66 & 5 & 5 & 0.64 & $14 \%$ & -1.87 \\
\hline $\begin{array}{l}\text { Particular importance is attached to the } \\
\text { relationship with employees }(n=150)\end{array}$ & 4.77 & 5 & 5 & 0.48 & $10 \%$ & -1.97 \\
\hline
\end{tabular}

Source: authors' own editing. Note: on a scale from 1 to 5 , where 1 stands for strong disagreement and 5 for strong agreement

Table 2 shows the measurement variables (statements) measuring relationship marketing and their descriptive statistical characteristics. Based on the mean values, it can be concluded that relationship marketing is generally accepted by the companies surveyed and it is considered important by them to establish a proper relationship with those involved in the business. Both the most common and the mean value show "strong agreement", which supports the importance of relationship marketing, more precisely, that it is considered important by the respondents.

The standard deviation and the coefficient of variation indicate that there is no significant difference in the attitudes of respondents. Regarding relationship marketing, the companies in the sample can be considered homogeneous, the coefficient of variation remains below $16 \%$ in all the cases. On examining the skewness index, a skewed distribution significantly to the left of the normal distribution can be observed, which means that the agreeing responses "thicken". This skewness is outstanding when there is a sign of self-interest (long-term partnerships are based on mutual satisfaction). However, it is important to note that although there is significant agreement on all indicators of relationship marketing, all the statements relate to the perceived acceptance of relationship marketing and not to the actual behaviour followed. Thus, the statements measure merely the extent to which companies agree with relationship marketing and consider it important, yet it does not provide feedback on the extent to which this is reflected in their behaviour. 
Table 3: Integrated marketing

\begin{tabular}{|l|c|c|c|c|c|c|}
\hline Statement (number of items) & Mean & Median & Mode & $\begin{array}{c}\text { Standard } \\
\text { deviation }\end{array}$ & $\begin{array}{c}\text { Coefficient } \\
\text { of variation }\end{array}$ & Skewness \\
\hline $\begin{array}{l}\text { All the units and all the employees of the } \\
\text { company have a role in creating value. } \\
(n=150)\end{array}$ & 4.63 & 5 & 5 & 0.60 & $13 \%$ & -1.37 \\
\hline $\begin{array}{l}\text { The marketing activities are coordinated } \\
\text { (products, pricing, sales, marketing } \\
\text { communication). }(n=149)\end{array}$ & 4.17 & 4 & 5 & 0.93 & $22 \%$ & -1.23 \\
\hline $\begin{array}{l}\text { Our marketing activities are planned in } \\
\text { advance. }(n=149)\end{array}$ & 3.79 & 4 & 5 & 1.09 & $29 \%$ & -0.55 \\
\hline $\begin{array}{l}\text { When designing a marketing program, we } \\
\text { consider the impact it has on other } \\
\text { activities. }(n=148)\end{array}$ & 4.01 & 4 & 5 & 1.02 & $25 \%$ & -0.99 \\
\hline $\begin{array}{l}\text { Marketing is a company-level activity and } \\
\text { not the job of a single person or } \\
\text { department. }(n=147)\end{array}$ & 4.05 & 4 & 5 & 1.21 & $30 \%$ & -1.21 \\
\hline
\end{tabular}

Source: authors' own editing. Note: on a scale from 1 to 5 , where 1 stands for strong disagreement and 5 for strong agreement

The measurement variables (statements) measuring integrated marketing and their descriptive statistical characteristics are shown in Table 3. Based on the mean values, signs of agreement can be observed in this case, as well. Although the most common response is "strong agreement", a more significant variance and heterogeneity can be seen in the attitudes of the companies surveyed.

With a low standard deviation, there is significant agreement among respondents on accepting that all units and employees in a company have a role in value creation, as evidenced by the left skewness of the density function. Compared to this indicator, a lower mean score and a higher relative standard deviation can be found for the other statements. This is probably due to the fact that these statements already refer partly to the behaviour of integrated marketing, thus in these cases it is no longer enough to agree with the content of the statement. It already incorporates some visible, tangible content and behavioural consequences, i.e. companies coordinate marketing tools, plan marketing programs and also potential impacts are taken into consideration in planning.

In the case of the last statement, a significant (30\%) relative standard deviation can be observed, which may have two causes: (1) it may result from the discrepancy between the values professed and followed, i.e. respondents agree that marketing is a company-level activity and not the job of a single person or department, however, this is not the case in actual practice; (2) incorrect decoding of the question can also result in higher variance, because if the respondent misunderstands the question, it can also be decoded as whether the company has a separate marketing department or marketing staff. 
Table 4: Internal marketing

\begin{tabular}{|l|c|c|c|c|c|c|}
\hline \multicolumn{1}{|c|}{ Statement (number of items) } & Mean & Median & Mode & $\begin{array}{c}\text { Standard } \\
\text { deviation }\end{array}$ & $\begin{array}{c}\text { Coefficient } \\
\text { of variation }\end{array}$ & Skewness \\
\hline $\begin{array}{l}\text { We consider it important to employ, train } \\
\text { and motivate employees who are ready to } \\
\text { serve customers. }(n=148)\end{array}$ & 4.41 & 5 & 5 & 0.85 & $19 \%$ & 2.92 \\
\hline $\begin{array}{l}\text { We consider it important that marketing } \\
\text { and market goals are known to everyone } \\
\text { within the organization }(n=148)\end{array}$ & 4.01 & 4 & 4 & 0.96 & $24 \%$ & 0.60 \\
\hline $\begin{array}{l}\text { In-house marketing activities are just as } \\
\text { important as those outside the company. } \\
(n=143)\end{array}$ & 3.98 & 4 & 5 & 0.99 & $25 \%$ & 0.23 \\
\hline $\begin{array}{l}\text { Managers share key information about the } \\
\text { organization. }(n=149)\end{array}$ & 4.67 & 5 & 5 & 0.60 & $13 \%$ & 3.18 \\
\hline $\begin{array}{l}\text { In order to meet customer needs, } \\
\text { cooperation and proper communication } \\
\text { between employees are essential. }(n=147)\end{array}$ & 4.81 & 5 & 5 & 0.46 & $10 \%$ & 5.29 \\
\hline
\end{tabular}

Source: authors' own editing. Note: on a scale from 1 to 5 , where 1 stands for strong disagreement and 5 for strong agreement

Table 4 shows the internal marketing measurement variable. As can be seen, the lowest mean score was associated with the statement that both external and internal marketing activities are important. It can be assumed that this is due to the lack of internal PR. Although an increasing number of large companies have internal marketing and internal PR departments, this can still be considered incomplete for SMEs. However, it can also be stated that the sample is relatively homogeneous, as the relative standard deviation remains below $25 \%$ in all the cases.

The statements about performance marketing are listed in the Table 5. The performance marketing pillar combines the idea of societal orientation and the importance of performance measurement, i.e. that the company must be aware of all the effects of its marketing activities, with regard to both what affects the company's effectiveness (profitability, return, efficiency) and what affects those involved in the company and the environment of the company (externalities). As can be concluded from the table, the importance of performance measurement is acknowledged in most cases (mean 4.45), although the effectiveness of marketing activities is less measured. This may be due to the fact that measuring marketing activity requires a greater degree of professional knowledge, which is not necessarily the case for SMEs. 
Table 5: Performance marketing

\begin{tabular}{|l|c|c|c|c|c|c|}
\hline \multicolumn{1}{|c|}{ Statement (number of items) } & Mean & Median & Mode & $\begin{array}{c}\text { Standard } \\
\text { deviation }\end{array}$ & $\begin{array}{c}\text { Coefficient } \\
\text { of variation }\end{array}$ & Skewness \\
\hline $\begin{array}{l}\text { It is considered important to be aware of the } \\
\text { performance (financial and non-financial } \\
\text { impacts) of our marketing activities. }(n=148)\end{array}$ & 4.45 & 5 & 5 & 0.88 & $20 \%$ & 3.05 \\
\hline $\begin{array}{l}\text { When making marketing decisions, } \\
\text { financial and profitability aspects are also } \\
\text { taken into account. } n=148)\end{array}$ & 4.45 & 5 & 5 & 0.85 & $19 \%$ & 3.15 \\
\hline $\begin{array}{l}\text { The effectiveness of our marketing activities } \\
\text { (e.g. market share, returning customers, } \\
\text { customer satisfaction, product quality) is } \\
\text { measured. }(n=148)\end{array}$ & 3.95 & 4 & 5 & 1.14 & $29 \%$ & 0.15 \\
\hline $\begin{array}{l}\text { Corporate social responsibility is considered } \\
\text { important. }(n=148)\end{array}$ & 4.14 & 4 & 5 & 0.93 & $23 \%$ & 0.81 \\
\hline $\begin{array}{l}\text { Ethical, environmental, legal and social } \\
\text { considerations must also be taken into } \\
\text { account when making marketing } \\
\text { decisions. } n=148)\end{array}$ & 4.19 & 4 & 5 & 1.00 & $24 \%$ & 1.77 \\
\hline $\begin{array}{l}\text { Our company conducts or participates in } \\
\text { programs that support charity or social } \\
\text { responsibility or social cause. }(n=148)\end{array}$ & 3.96 & 4 & 5 & 1.06 & $27 \%$ & 0.34 \\
\hline
\end{tabular}

Source: authors' own editing. Note: on a scale from 1 to 5 , where 1 stands for strong disagreement and 5 for strong agreement.

\subsection{Confirmatory factor analysis (CFA)}

Confirmatory factor analysis was programmed using the lavaan $\mathrm{R}$ package. The model was constructed based on a priori estimation. In the course of the analysis, the measurement variables that did not have a significant explanatory power were excluded in the first round, and then the variables whose factor loading was considered low in the model were also excluded. In order to improve the fit indices, the covariance between the measurement variables belonging to the same latent variable in the model was allowed, however, the conditions of the model were not violated by this concession. Model fit indicators were determined by Hooper et al. (2008) and Hair et al. (2010). The fit of the model and the acceptance range are shown in the Table 6.

Table 6: Fit indices of the CFA analysis of holistic marketing

\begin{tabular}{|l|c|c|}
\hline \multicolumn{1}{|c|}{ Indicator } & Criterion & Fitting of the empirical model \\
\hline$\chi^{2}$ (szf.) & & $115.449(92)$ \\
\hline$\chi^{2}$ stat. $\mathrm{p}$-value & $\geq 0.05$ & 0.051 \\
\hline CFI & $\geq 0.90$ & 0.963 \\
\hline GFI & $\geq 0.90$ & 0.912 \\
\hline AGFI & $\geq 0.60$ & 0.870 \\
\hline RMSEA & $\leq 0.08$ & 0.043 \\
\hline TLI & $\geq 0.90$ & 0.952 \\
\hline IFI & $\geq 0.09$ & 0.965 \\
\hline
\end{tabular}

Source: authors' own editing

The convergent validity of the holistic marketing concept model was examined using the AVE indicator as well as the factor loadings for each measurement variable. AVE indicator values are as follows: integrated marketing $=0.57$; internal marketing $=0.56$; societal marketing $=$ 0.48 ; relationship marketing $=0.53$. In one case (societal marketing), the value of the AVE indicator falls short of expectations (Hair et al., 2010). However, according to Lam (2012), if it falls only slightly below the 0.5 threshold, but at the same time the value of CR meets the expected value level (0.6), the convergence of the measurement variables towards the latent variable is acceptable (that is, our indicators/scales measure the latent variable for which they 
are intended). Presumably, convergence was compromised in this case because there is a behavioural element among the measurement variables (the company conducts or participates in a social responsibility project) and a statement relating to two values, and as a result of the contradiction between the values perceived and followed, there is a dissonance between the measurement variables according (Wimmer, 2010). Based on the above, it can be concluded that the convergent validity of the holistic marketing concept model exists.

\subsection{Exploratory factor analysis (EFA)}

Having confirmed by CFA analysis that the data fit our pre-assumed structure, we checked the ordering of the statements into structures with EFA analysis and prepared our data for further studies for data reduction. This was performed using the maximum likelihood method. The total explained variance is above $60 \%$ and it is clearly visible that the measurement variables of the model are grouped into the latent variables of the a priori estimate. During EDF, only the measurement variables accepted based on the CFA were included in the study (Table 7).

Table 7: The adapted model of the holistic marketing concept $(n=150)$

\begin{tabular}{|l|l|l|l|l|}
\hline \multicolumn{1}{|c|}{ Statement } & IGM & ILM & SM & RM \\
\hline Our marketing activities are planned in advance. & $\mathbf{0 . 8 2}$ & 0.06 & 0.06 & 0.02 \\
\hline $\begin{array}{l}\text { The marketing activities are coordinated (products, pricing, sales, marketing } \\
\text { communication). }\end{array}$ & $\mathbf{0 . 8 0}$ & 0.07 & 0.02 & 0.01 \\
\hline $\begin{array}{l}\text { It is considered important to be aware of the performance (financial and non- } \\
\text { financial impacts) of our marketing activities. }\end{array}$ & $\mathbf{0 . 7 7}$ & 0.17 & 0.00 & - \\
\hline $\begin{array}{l}\text { When making marketing decisions, financial and profitability aspects are } \\
\text { also taken into account. }\end{array}$ & $\mathbf{0 . 7 6}$ & 0.18 & 0.21 & 0.02 \\
\hline $\begin{array}{l}\text { When designing a marketing program, we consider the impact it has on other } \\
\text { activities. }\end{array}$ & $\mathbf{0 . 7 1}$ & 0.20 & 0.26 & 0.13 \\
\hline $\begin{array}{l}\text { The effectiveness of our marketing activities (e.g. market share, returning } \\
\text { customers, customer satisfaction, product quality) are measured. }\end{array}$ & $\mathbf{0 . 6 4}$ & 0.14 & 0.22 & 0.00 \\
\hline \hline $\begin{array}{l}\text { We consider it important that marketing and market goals are known to } \\
\text { everyone within the organization. }\end{array}$ & 0.27 & $\mathbf{0 . 7 9}$ & -0.05 & 0.07 \\
\hline $\begin{array}{l}\text { In-house marketing activities are just as important as those outside the } \\
\text { company. }\end{array}$ & 0.09 & $\mathbf{0 . 7 9}$ & 0.27 & 0.03 \\
\hline $\begin{array}{l}\text { We consider it important to employ, train and motivate employees who are } \\
\text { ready to serve customers. }\end{array}$ & 0.18 & $\mathbf{0 . 6 5}$ & -0.02 & 0.02 \\
\hline \hline $\begin{array}{l}\text { Our company conducts or participates in programs that support charity or } \\
\text { social responsibility or social cause. }\end{array}$ & 0.10 & -0.11 & $\mathbf{0 . 7 8}$ & - \\
\hline Corporate social responsibility is considered important. & 0.14 & 0.17 & $\mathbf{0 . 7 4}$ & 0.13 \\
\hline $\begin{array}{l}\text { Ethical, environmental, legal and social considerations must also be taken } \\
\text { into account when making marketing decisions. }\end{array}$ & 0.43 & 0.14 & $\mathbf{0 . 5 5}$ & 0.11 \\
\hline \hline Particular importance is attached to the relationship with the customers. & 0.04 & -0.01 & 0.00 & $\mathbf{0 . 8 2}$ \\
\hline $\begin{array}{l}\text { Particular importance is attached to the relationship with partners (suppliers, } \\
\text { allies, distributors, agencies, investors). }\end{array}$ & 0.03 & 0.32 & 0.00 & $\mathbf{0 . 7 0}$ \\
\hline Long-term partnerships are based on mutual satisfaction. & 0.01 & -0.10 & 0.11 & $\mathbf{0 . 6 6}$ \\
\hline
\end{tabular}

Source: authors' own editing. Note: RM=relationship marketing, IGM=integrated marketing, ILM=internal marketing, $\mathrm{SM}=$ societal marketing.

\subsection{Discriminant validity}

The results of the discriminant validity study are illustrated in Table 8. The AVE index can be seen in the second column of the Table 8 , the correlation coefficients in the third, fourth, fifth, and sixth columns and the square root of the AVE index is shown in bold. If the square root of the AVE indicator is compared with the individual correlation coefficients, discriminant validity can be determined, that is, the Fornell - Larcker criterion has been met. 
Table 8: Discriminant validity

\begin{tabular}{|l|c|c|c|c|c|}
\hline & AVE & RM & IGM & ILM & SM \\
\hline KM & 0.531 & $\mathbf{0 . 7 2 9}$ & & & \\
\hline IM & 0.567 & 0.146 & $\mathbf{0 . 7 5 3}$ & & \\
\hline BM & 0.562 & 0.243 & 0.500 & $\mathbf{0 . 7 5 0}$ & \\
\hline TkM & 0.481 & 0.241 & 0.630 & 0.352 & $\mathbf{0 . 6 9 4}$ \\
\hline
\end{tabular}

Source: authors' own editing. Note: $\mathrm{RM}=$ relationship marketing, IGM=integrated marketing, ILM=internal marketing, $\mathrm{SM}=$ societal marketing.

\subsection{Reliability tests}

The reliability of the holistic marketing scales (measurement model) was examined using three indicators: Cronbach's alpha, composite reliability, McDonald's omega. All indicators are acceptable above a threshold of 0.6. This has been accomplished by the scales used. However, in several cases (e.g. relationship marketing) a low value of the indices can be observed, which reflects weak or medium reliability. In our opinion, the reason for this is to be found in the number of items and in the composition of the sample (micro, small and medium-sized companies), as alpha and omega are test-based test methods that may be particularly sensitive to items (Table 9).

Table 9: Reliability indicators of validated scales

\begin{tabular}{|l|c|c|c|}
\hline \multicolumn{1}{|c|}{ Dimension } & Cronbach's alpha & $\begin{array}{c}\text { Composite reliability } \\
(\mathrm{CR})\end{array}$ & $\begin{array}{c}\text { McDonald's omega } \\
(\mathrm{ML})\end{array}$ \\
\hline Integrated marketing & 0.87 & 0.88 & 0.91 \\
\hline Internal marketing & 0.70 & 0.78 & 0.71 \\
\hline Societal marketing & 0.69 & 0.74 & 0.61 \\
\hline Relationship marketing & 0.65 & 0.65 & 0.62 \\
\hline
\end{tabular}

Source: authors' own editing

\section{Conclusion}

The concept of market orientation showing the realization of the marketing concept, was developed in the 1990s and several scales were developed to measure it (MARKOR, MKTOR, DFW scales). However, the market has undergone significant changes over the past 30 years and the marketing concept itself has further evolved. Numerous attempts have been made to adapt the scales to the changes with varying degrees of success. The present study also attempts to develop a scale to measure the level of market orientation based on the holistic marketing concept, one of the most modern approaches to the marketing concept.

The comparison of the results of the current study is complicated, because empirical study on the measurement and validation of Kotler's holistic marketing concept is not available based on the author's secondary research. However, the tools for measuring market orientation have been examined in more depth in a number of cases. Oczkowski and Farrell (1997) compared the MKTOR and MARKOR scales in terms of validity and reliability. Their findings suggest that both measurement scales are problematic with an acceptable fit obtained only when several items were deleted. Jangl (2016) tested the modified version of the MKTOR scale, the MMOS scale on a sample of German high-tech companies. His research may serve as an evidence for the suitability of the instrument for measuring market orientation in European cultural conditions. Carson et al. (2004) examined holistic tourist industry marketing in four dimensions, which are as follows:: infrastructure, facilities, communication and site maintenance. In their research, the validation of the applied model did not appear. But it can be stated that their approach differs significantly from Kotler's. The term holistic marketing, although used in many studies, is most often not related to Kotler's model. This is why the 
present study represents a new approach, more precisely a new application of Kotler's model, which is essentially a possible market orientation measurement model.

The possible applications of the holistic marketing concept as a market orientation model among Hungarian SMEs were examined. The holistic marketing concept was modelled based on Kotler and Keller (2012) and examined on a sample compising 150 companies. The model meets both reliability and validity requirements. However, the limitation of the results is that according to several indicators, reliability is barely within the acceptable range when modelling relationship marketing. It is advisable, in our view, to subject the model to further testing and to test its extent through further data collection. Another research direction could be to compare the level of market orientation measured using the holistic marketing concept with the results of other previous market orientation measurement tools (MARKOR, MKTOR, DFW).

The current results indicate that all the dimensions of holistic marketing can be found in Hungarian practice as well, which can be considered positive not only from the point of view of modelling, but also implies that Hungarian SMEs, although sometimes with significant variance, have the resources of a modern marketing approach (competence and skills). However, the performance marketing dimension of the original model (Kotler and Keller 2012) could be modelled only to a limited extent, i.e. we were able to measure societal marketing, which is one of the elements of performance marketing. The reason for this is to be found in the fact that the population surveyed may lack the abilities and skills needed to measure the effectiveness of marketing activities.

\section{References}

[1] AVlONITIS, G. J. and S. P. GOUNARIS, 1999. Marketing Orientation and Its Determinants: an Empirical Analysis. European Journal of Marketing, 33(11-12), 10031037. ISSN 0309-0566.

[2] BAREITH T., GY. KÖVÉR and ZS. POLERECZKI, 2013. A magyar élelmiszeripari kisés közepes vállalkozások piacorientációjának mérési lehetőségei. (Possibilities of Measuring the Market Orientation of Small and Medium-Sized Enterprises in the Hungarian Food Industry.) Élelmiszer, Táplálkozás és Marketing, 9(1), 29-37. ISSN 17863422 .

[3] BECKER, J. and C. HOMBURG, 1999. Market-Oriented Management: A System-Based Perspective. Journal of Market Focused Management, 4(1), 17-41. ISSN 1382-3019.

[4] BRETTEL, M., A. ENGELEN, F. HEINEMANN and A. KESSELL, 2007. The Role of Market-Oriented Organizational Culture in New Entrepreneurial Ventures. Journal of Research in Marketing and Entrepreneurship, 9(1), 40-66. ISSN 1471-5201.

[5] CARSON, D., A. GILMORE, P. ASCENCAO and L. FAWCETT, 2004. Holistic Tourist Industry Marketing: Significant Deficiencies in Relation to Natural Sites, Journal of Marketing Theory and Practice, 13(4), 49-59. ISSN 1069-6679.

[6] COLEY, L. and M. C. COOPER, 2010. Is "Consumer Orientation" a Dimension of Market Orientation in Consumer Markets? Journal of Marketing Theory and Practice, 18(2), 141154. ISSN 1069-6679.

[7] DAWES, J., 2000. Market Orientation and Company Profitability: Further Evidence Incorporating Longitudinal Data. Australian Journal of Management, 25(2), 173-199. ISSN 0312-8962. 
[8] DESPHANDÉ R., J. U. FARLEY and F. E. WEBSTER JR., 1993. Corporate Culture, Customer Orientation and Innovativeness in Japanese Firms: A Quadrad Analysis. Journal of Marketing, 57(1), 23-37. ISSN 0022-2429.

[9] DESPHANDÉ, R. and J. U. FARLEY, 2004. Organizational Culture, Market Orientation, Innovativeness, and Firm Performance: an International Research Odyssey. International Journal of Research in Marketing, 21, 3-22. ISSN 0167-8116.

[10] FARRELL, M. A., 2002. Critique of the Development of Alternative Measures of Market Orientation. Marketing Bulletin, 13, 31-13. ISSN 1176-645X.

[11] FORNELL, C. and D. F. LARCKER, 1981. Evaluating Structural Equation Models with Unobservable Variables and Measurement Error. Journal of Marketing Research, 18, 3950. ISSN 0022-2437.

[12] FRÖSÉN, J., J. LUOMA, M. JAAKKOLA, H. TIKKANEN and J. ASPARA, 2016. What Counts Versus What Can Be Counted: The Complex Interplay of Market Orientation and Marketing Performance Measurement. Journal of Marketing, 80(3), 60-78. ISSN 00222429.

[13] GILL, J., P. JOHNSON and M. CLARK, 2010. Research Methods for Managers. 4nd ed. SAGE Publications. ISBN 978-1847870940

[14] HAIR, J. F., W. C. BLACK, B. J. BABIN and R. E. ANDERSON, 2010. Multivariate Data Analysis. 7nd ed. Prentice Hall, Upper Saddle River, New Jersey. ISBN 9780138132637.

[15] GONZÁLEZ-BENITO, Ó. and J. GONZÁLEZ-BENITO, 2005. Cultural vs. Operational Market Orientation and Objectives vs. Subjective Performance: Perspective of Production and Operations. Industrial Marketing Management, 34(8), ISSN 797-829. 0019-8501.

[16] HAJJAT, M. M., 2002. Customer Orientation: Construction and validation of the CUSTOR Scale. Marketing Intelligence and Planning, 20(7), 428-444. ISSN 0263-4503.

[17] HARRISON-WALKER, J. L., 2001. The Measurement of a Market Orientation and Its Impact on Business Performance. Journal of Quality Management, 6, 137-172. ISSN 1084-8568.

[18] HOOPER, D., J. COUGHLAN and M. MULLEN, 2008. Structural Equation Modelling: Guidelines for Determining Model Fit. Electronic Journal of Business Research Methods, 6(1), 53-60. ISSN 1477-7029.

[19] JANGL, P., 2016. Model of Market Orientation of High-tech Firms in Germany: Validation Study. Verslas: teorija ir praktika, 17(3), 216-224. ISSN 1822-4202.

[20] KOHLI, A. K. and B. J. JAWORSKI, 1990. Market Orientation: The Construct, Research Proposition and Managerial Implications. Journal of Marketing, 54(2), 1-18. ISSN 00222429.

[21] KOHLI, A. K., B. J. JAWORSKI and A. KUMAR, 1993. MARKOR: A Measure of Market Orientation. Journal of Marketing Research, 30(4), 467-477. ISSN 00222437.|

[22] KOTLER P. and K. L. KELLER, 2012. Marketingmenedzsment. Akadémiai Kiadó, Budapest. ISBN 9789630597784.

[23] KOVÁCS, B., Z. SZAKÁLY, E. KONTOR and ZS. POLERECZKI, 2017. A piacorientáció kulturális és magatartási megközelítésének empirikus összehasonlító elemzése. (An Empirical Comparative Analysis of the Cultural and Behavioral Approach 
to Market Orientation.) Jelenkori Társadalmi és Gazdasági Folyamatok, 12(4), 159-174. ISSN 1788-7593.

[24] LAFFERTY, B. A. and G. T. M. HULT, 2001. A Synthesis of Contemporary Market Orientation Perspectives. European Journal of Marketing, 35(1-2), 92-109. ISSN 03090566.

[25] LAM, L. W., 2012. Impact of Competitiveness on Salespeople's Commitment and Performance. Journal of Business Research, 65(9), 1328-1334. ISSN: 0148-2963.

[26] NARVER, J. and S. SLATER, 1990. The Effect of Marketing Orientation on Business Profitability. Journal of Marketing, 54, 80-116. ISSN 0022-2429.

[27] OCZKOWSKI, E. and M. A. FARREL, 1997. An Analysis of the MKTOR and MARKOR Measures of Market Orientation: An Australian Perspective. Marketing Bulletin, 8, 30-40. ISSN 1176-645X.

[28] RUEKERT, R. W., 1992. Developing a Market Orientation: An Organizational Strategy Perspective. International Journal of Research in Marketing, 9(3), 225-245. ISSN 01678116.

[29] SHAPIRO, B., 1988. What the Hell is „Market-Oriented”? Harvard Business Review, 67(6), 119-125. ISSN 0017-8012.

[30] WIMMER, Á., 2010. A piaci normák sérülése, az üzleti döntések és a vállalati hatékonyság. (Violation of market norms, business decisions and corporate efficiency.) Vezetéstudomány, 41(7-8), 16-24. ISSN 0133-0179. 